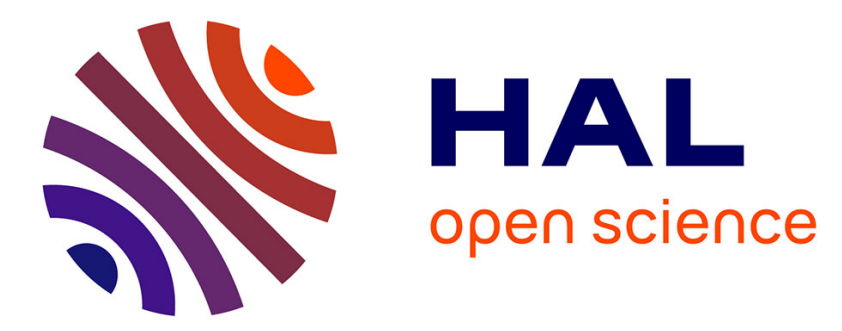

\title{
Study on the in-process measurements of the surface roughness of Douglas fir green veneers with the use of laser profilometer
}

Stanislaw Stefanowski, Rémy Frayssinhes, Grzegorz Pinkowski, Louis Denaud

\section{- To cite this version:}

Stanislaw Stefanowski, Rémy Frayssinhes, Grzegorz Pinkowski, Louis Denaud. Study on the in-process measurements of the surface roughness of Douglas fir green veneers with the use of laser profilometer. European Journal of Wood and Wood Products, 2020, 78 (3), pp.555-564. 10.1007/s00107-020-015296. hal-02864727

\section{HAL Id: hal-02864727 https://hal.science/hal-02864727}

Submitted on 11 Jun 2020

HAL is a multi-disciplinary open access archive for the deposit and dissemination of scientific research documents, whether they are published or not. The documents may come from teaching and research institutions in France or abroad, or from public or private research centers.
L'archive ouverte pluridisciplinaire HAL, est destinée au dépôt et à la diffusion de documents scientifiques de niveau recherche, publiés ou non, émanant des établissements d'enseignement et de recherche français ou étrangers, des laboratoires publics ou privés. 


\title{
Study on the in-process measurements of the surface roughness of Douglas fir green veneers with the use of laser profilometer
}

\author{
Stanisław Stefanowski ${ }^{1} \cdot$ Rémy Frayssinhes $^{2} \cdot$ Grzegorz Pinkowski $^{1} \cdot$ Louis Denaud $^{2}$
}

\begin{abstract}
The presented research concerns the use of a laser profilometer to measure the surface roughness of green Douglas fir heartwood veneers during the peeling process. It investigates the effect of various process parameters on the surface quality. Three experiments were carried out with a single variable factor for each experiment: log centration, soaking temperature and cutting speed. Moreover, the origin of the surface roughness of Douglas fir green veneers was investigated. The study shows that laser profilometer seems to be a useful equipment in online measurement of surface roughness of green veneers. Based on the experiment results it was stated that surface roughness of Douglas fir veneers is characterized by large differentiation depending on the location on the veneer. The performed analysis shows that the surface roughness of Douglas fir green veneer could be improved when using relatively high cutting speed, not too high steaming temperature and logs with a centered core. The presented study shows that the laser profilometer can be effectively applied to the measurement and evaluation of green veneers during the peeling process and that there is still an area to develop this methodology.
\end{abstract}

\section{Introduction}

Roughness is one of the most frequently used parameters in the analysis of the quality of wood surface. In veneer production, the surface roughness, beside lathe check occurrence and thickness variation, can be a proper indicator of veneer quality. Roughness of the veneers is important mainly in case of their further processing, especially in production of plywood and LVL. It has been previously stated that surface roughness has a significant effect on the gluing ability of veneers, glue consumption, penetration of adhesive into the veneer, and bonding strength of veneer products. Sogutlu (2017) found that the lower the roughness of wood, the lower is the glue consumption. Faust and Rice (1986) reported that adhesive strength is up to $30 \%$ higher for veneers with a smooth surface than with a rough surface. DeVallance et al. (2007) tested gluebond quality of Douglas

Louis Denaud

louis.denaud@ensam.eu

1 Department of Woodworking Machinery and Basis of Machines Construction, Poznan University of Life Sciences, ul. Wojska Polskiego 38/42, 60-627 Poznań, Poland

2 Arts et Metiers Institute of Technology, LABOMAP, HESAM Université, rue Porte de Paris, 71250 Cluny, France fir plywood showing that the percent wood failure can be increased by reducing veneer roughness. Neese et al. (2004) conducted similar experiments and noticed the same dependence. Improving the quality of veneer surface can be done by conducting additional technological processes such as sanding or veneer densification (Candan et al. 2010; Bekhta et al. 2017), which allow obtaining better veneer properties, among others lower surface roughness (Diouf et al. 2011; Bekhta et al. 2014). However, in industrial process monitoring of the surface roughness during the peeling process and decreasing the roughness to the optimal level by appropriate selection of technological parameters can be necessary to obtain an acceptable surface quality.

The effects of pre-treatment and peeling parameters, such as cutting speed, soaking temperature, soaking time, clearance angle, etc. on the surface quality of veneers are considerable, but still not precisely understood, especially in terms of differentiation in structure and properties of different wood species. Tanritanir et al. (2006) stated that the steaming time has a significant effect on the surface roughness of beech veneers. Dundar et al. (2008b) completed similar experiments and demonstrated that the soaking time increased the surface roughness of beech veneers peeled from heartwood. Rohumaa et al. (2016) investigated the effect of the soaking temperature on the surface quality of birch veneers showing that too low soaking temperature 
$\left(20{ }^{\circ} \mathrm{C}\right)$ causes high surface roughness of the loose side of veneers. Aydin et al. (2006) carried out research on a similar subject showing that surface roughness of spruce veneers obtained from the $\log$ with a temperature of $52^{\circ} \mathrm{C}$ was lower than when the log temperature was $32^{\circ} \mathrm{C}$.

In case of Douglas fir, which is a highly heterogenous species (Echols 1973; Vonnet et al. 1985), property selection of soaking and peeling parameters may have a crucial influence on the product quality. Corder and Atherton (1963) used air-flow arrangement to measure surface roughness of veneers. The authors stated that an increase in the temperature of logs during the peeling process increased the surface roughness of Douglas fir veneers peeled from sapwood, and they reported that the optimal temperature of wood is $60{ }^{\circ} \mathrm{C}$. Dupleix et al. (2013) also noted that soaking temperature has an effect on the lathe check distribution and depth. On the other hand, Hecker (1995a) found that the boiling time and the log temperature do not have a significant effect on the surface roughness, but it depends significantly on moisture content of wood during the peeling process. The author also showed that the surface roughness is higher for heartwood than for sapwood, what is directly connected to moisture content. The author used the contact stylus method to measure the surface roughness. However, most of the articles described above concern dry veneers. According to the authors' knowledge, there is no research on the surface roughness of green veneers, mainly because the stylus method of roughness measurement, which is most commonly used, is useless in green veneer evaluation, in particular in the case of continuous measurements.

Generally, methods of surface roughness measurement can be split into two categories: contact and non-contact. Methods from the first category are the most frequently used ones, and they are common in laboratory measurements, in particular for solid wood products (Kilic et al. 2006; Thoma et al. 2015), but also for wood veneers (Tanritanir et al. 2006; Dundar et al. 2008a; Candan et al. 2010; Bekhta et al. 2014). The main weakness of this approach is the contact between the fibers and the stylus, especially for fuzzy surfaces. The second category concerns mainly optical and laser scanning methods (Lundberg and Porankiewicz 1995; Sandak et al. 2004). Previous research, conducted in recent years, showed that these methods have larger potential for the use in wood processing than contact methods, in particular in on-line measurement of the surface roughness in manufacturing lines. A comparison of stylus and optical methods was done by Funck et al. (1993). Sandak and Tanaka (2003) showed that using a laser profilometer to measure roughness allows obtaining proper images of wood surfaces. Therefore, this solution can be applied to monitor and evaluate the surface roughness of veneers during the peeling process. Goli and Sandak (2016) used laser profilometer and optical camera to evaluate and image the surface of machined wood and proposed a method for automated assessment of the surface quality. It is assumed that only an optical measuring system can be relevant to measure online green veneer surface roughness, which is required to be able to adapt both steaming temperature and peeling process settings. This is especially true for wood species known to produce fuzzy surfaces due to the Horner effect as Douglas fir does (Mothe 1988). This phenomenon is perfectly described in Thibaut et al. (2016). According to the authors, a bundle of material is compacted ahead of the tool tip until separation can occur with small cracks above and beneath the cutting direction together with a quick swelling back of the bundle, as in the movement of an accordion. This was called the Horner effect. This phenomenon is occurring because of the low wood density of Douglas fir early wood especially when the logs were previously soaked or steamed.

The aim of this study was to use a laser profilometer to measure the surface roughness of thigh side of green Douglas fir (Pseudotsuga menziesii) heartwood veneers during the peeling process. The loose side of the veneer is highly influenced by the lathe check phenomenon and both surfaces are sensitive to cutting quality. It was assumed that the thigh side of the veneer was enough to measure the veneer surface quality. The effect of soaking temperature, log centration and cutting speed on green veneer surface roughness was investigated. Moreover, the origin of the surface roughness of Douglas fir veneers was analyzed.

This species represents a great potential to produce plywood or LVL panels in France. According to the authors` best knowledge, even if Douglas fir is one of the most peeled species in the world, there is no objective characterization of veneers by optical measurements.

\section{Materials and methods}

\subsection{Peeling process}

Green Douglas fir logs (Pseudotsuga menziesii) were sawn into six $800 \mathrm{~mm}$ length logs. Prior to peeling, all $\operatorname{logs}$ were soaked for $48 \mathrm{~h}$ in hot water to insure reaching $60{ }^{\circ} \mathrm{C}$ at the log's core. Veneers were produced in LaBoMaP (ENSAM, Cluny, France) by a rotary peeling process using SEM S500 instrumented peeling machine.

Three experiments were carried out and analyzed separately, with one variable factor in each experiment: $\log$ centration with two logs from Matour (France), soaking temperature with two logs from St Germain la Montagne (France) and cutting speed with two $\log$ s from Matour (France). In total, $5 \operatorname{logs}$ were peeled during the study. The peeling process parameters for each experiment are presented in Table 1. The edge angle of the cutting knife was $21^{\circ}$ and the clearance angle was in the range of $0^{\circ}-1^{\circ}$. All 
Table 1 Parameters of the peeling processes carried out in this study

\begin{tabular}{llll}
\hline Variable factor & \multicolumn{3}{l}{ Process parameters } \\
\cline { 2 - 4 } & $\begin{array}{l}\text { Soaking tem- } \\
\text { perature }\left({ }^{\circ} \mathrm{C}\right)\end{array}$ & $\begin{array}{l}\text { Cutting } \\
\text { speed }(\mathrm{m} / \mathrm{s})\end{array}$ & Log centration \\
\hline Log centration & 65 & 2 & $\begin{array}{c}\text { Centered/non- } \\
\text { centered }\end{array}$ \\
$\begin{array}{l}\text { Soaking temperature } \\
\text { Cutting speed }\end{array}$ & $55 / 80$ & 2 & $\begin{array}{l}\text { Centered } \\
\text { Centered }\end{array}$ \\
\hline
\end{tabular}

logs were peeled without the angular pressure bar. According to previous test, the Horner effect is highly penalizing the final veneer quality when using the angular pressure bar since bundles of fibers stay stacked to the tools creating local veneer thickness variation. Veneer thickness was $3 \mathrm{~mm}$ in all analyzed cases.

Non-centered log for the first experiment was prepared from a tree with the core located slightly non-centered. The procedure of preparing the log is presented in Fig. 1.

\subsection{Surface roughness measurement}

Surface roughness of the veneers was measured using LJ-V7080 laser profilometer (Keyence, Itasca, IL, USA). Repeatability in Z-axis was $0.5 \mu \mathrm{m}$. The profilometer was installed in the peeling line $85 \mathrm{~mm}$ above the moving veneer. Data obtained from the profilometer were filtered to eliminate waviness of the profile using the high-pass filter with the cut-off length of $8 \mathrm{~mm}$. This value has been chosen based on ISO 4288 (1996), which says that if $R_{a}$ is in the range of $10-80 \mu \mathrm{m}$, then the cut off length should be $8 \mathrm{~mm}$. To filter and treat the data, Python with NumPy and Matplotlib packages in PyCharm software (JetBrains, Prague, Czech Republic) was used. An example of filtering results of veneer with a length of $1 \mathrm{~m}$ is shown in Fig. 2.

The surface roughness parameters were calculated in accordance with ISO 4287 (1997). The arithmetic mean surface roughness $\left(R_{a}\right)$ and the maximum height of the profile $\left(R_{z}\right)$ parameters were used. The reason for using these parameters is that $R_{a}$ is the most commonly used indicator in the research on surface roughness of wood (Aydin et al. 2006; Tanritanir et al. 2006; Dundar et al. 2008b; Rohumaa et al. 2016), while $R_{z}$ parameter allows to analyze the structure of wood, which contains deep cavities (Csanády and Magoss 2013). Roughness parameters were calculated using the following equations:

$R_{a}=\frac{1}{l_{m}} \int_{0}^{l m}|z(x)| * d x[\mu \mathrm{m}]$

$R_{z}=\frac{1}{5} *\left(Z_{1}+Z_{2}+Z_{3}+Z_{4}+Z_{5}\right)[\mu \mathrm{m}]$

The length of the measuring path $l_{m}$ was $40 \mathrm{~mm} . \mathrm{Z}_{1-5}$ is the distance between the highest peak and the deepest valley in the elementary section $l_{e}$ of the measuring path, which amounted to $8 \mathrm{~mm}$. Roughness parameters were calculated on 10 lines from the middle part of the measuring section. Then, for each measuring path $l_{m}$, mean values of $R_{a}$ and $R_{z}$ from 10 measuring lines were calculated, as presented in Fig. 3. Distance between each line was $0.1 \mathrm{~mm}$, so $1 \mathrm{~mm}$ width area was analyzed.

The calculation of the mean values from 10 middle sections of the measuring area helps getting representative information about the surface, which is mainly constituted of tracheids perpendicular to the measuring direction (see Fig. 5). Variability of the roughness is considerably higher in the measuring direction (veneer length in Fig. 3). However, the longitudinal variability may also affect the final results of the surface roughness. Figure 4 presents the roughness measurements of a $1 \mathrm{~m}$ veneer length. Each point on the graph represents $R_{a}$ on the measuring path $l_{m}(40 \mathrm{~mm})$, obtained from the 10 middle sections of the profile in accordance with the method described above. The presented standard deviation represents the variability of $R_{a}$ on each $l_{m}$ from 100 measuring sections, so from $10 \mathrm{~mm}$ width part of the veneer.

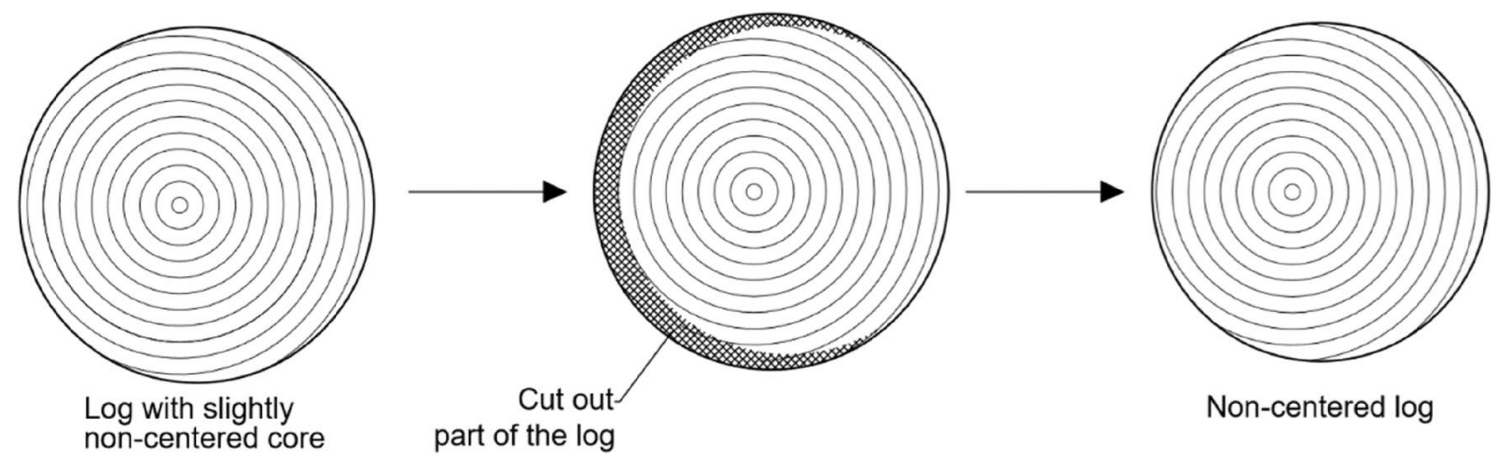

Fig. 1 Procedure of preparing non-centered log for the first experiment 
Fig. 2 An example of filtering results of the surface profile: a unfiltered surface profile (direct profile), $\mathbf{b}$ waviness profile of the surface, $\mathbf{c}$ roughness profile of the surface

Fig. 3 Sections of the surface roughness measurement with calculated mean line in a band on $1 \mathrm{~mm}$ width
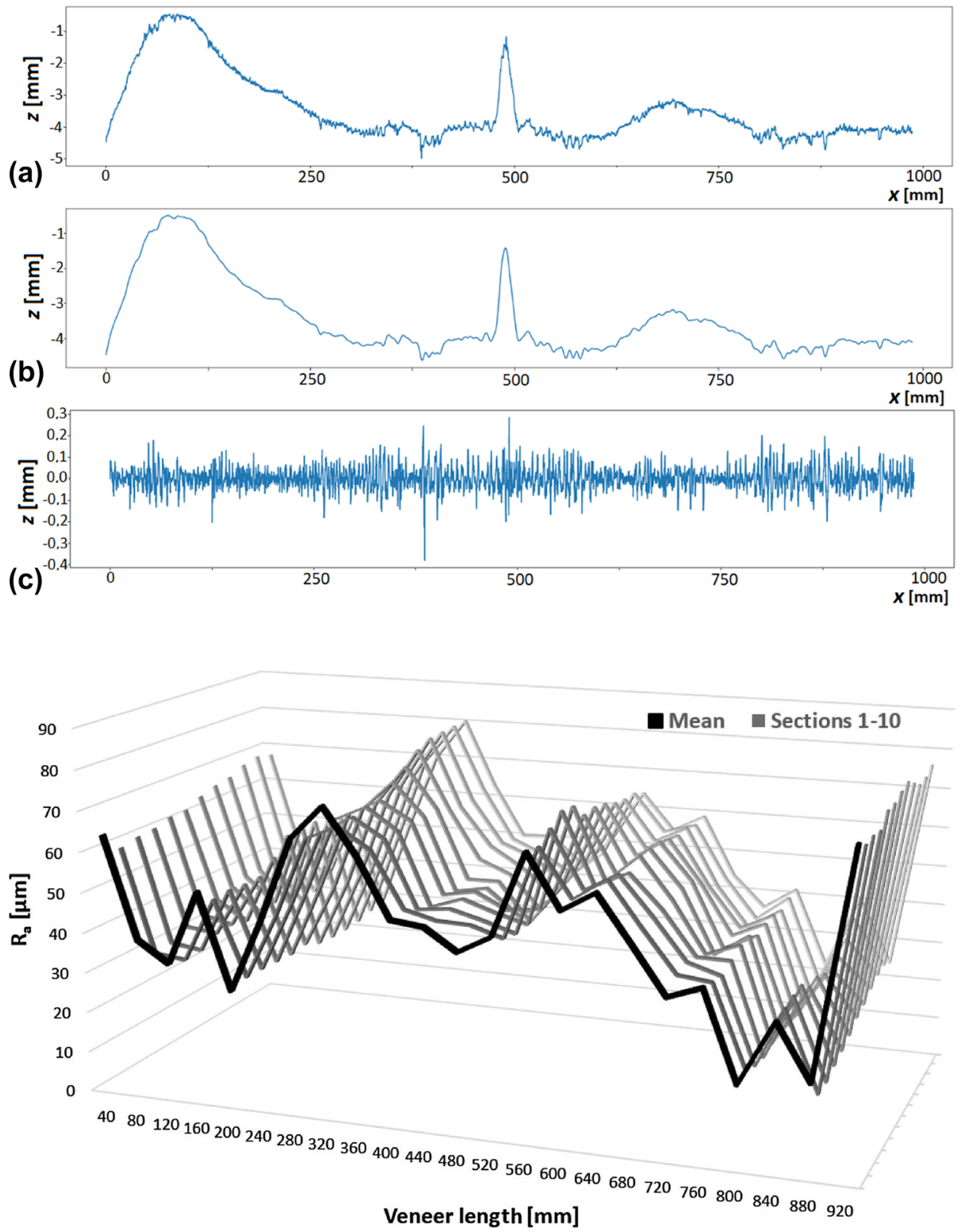

Veneer variability in the grain direction is not negligible. Standard deviation was higher especially when values of $R_{a}$ were also high. More precisely, earlywood seems to present the roughest surfaces.

The attempt to evaluate surface roughness of veneers using three dimensional parameters (3D surface map), as proposed by Goli and Sandak (2016) for solid wood machining, seems to be an article-relevant approach.

For each analyzed log, 125 measurements of roughness parameters from the last part of the veneer were analyzed. This part of the veneer was produced with stabilized cutting conditions (neither at the beginning nor at the end of the ribbon). In total, $5 \mathrm{~m}$ of veneer from each log was analyzed. Analysis was conducted only on the last $5 \mathrm{~m}$ of the veneer in order to analyze only a heartwood and thus avoid the effect of a sapwood on the results, which could perturb interpretation of the experiment.

In order to establish significant dependences between the results, the unequal variance t-test was completed at the significance level of $\alpha=0.05$. Statistical analysis and calculation of statistical indicators was done in Excel software (Microsoft, Redmond, WA, USA). 
Fig. 4 Results of $R_{a}$ measurement on one veneer. Each point represents mean from 10 measuring sections and standard deviation shows variability of 100 measuring sections
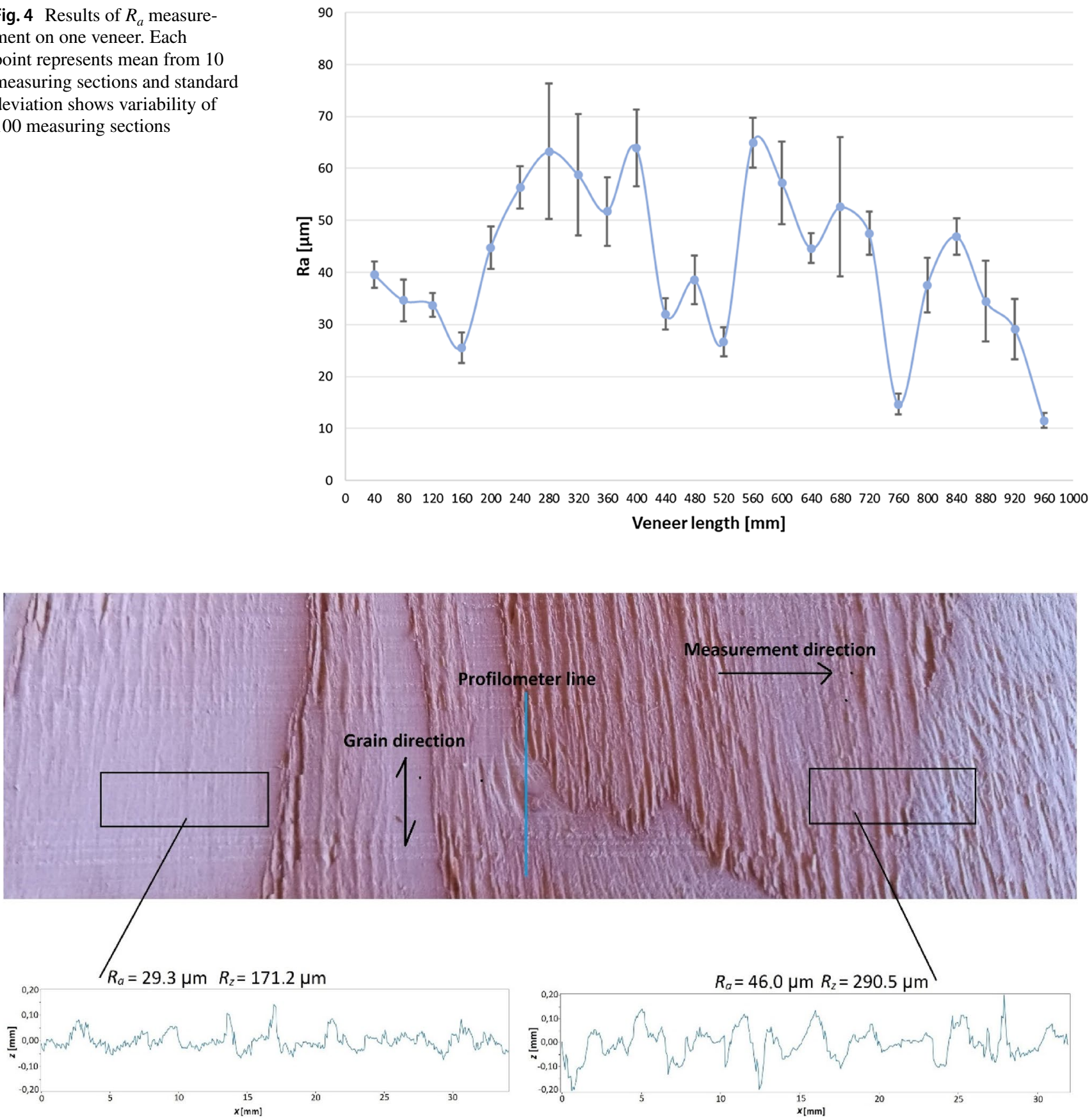

Fig. 5 An example of latewood (left) and earlywood (right) surface, roughness profiles and values of roughness parameters of the veneer

\section{Results and discussion}

\subsection{The origin of the surface roughness of Douglas fir green veneers}

The surface roughness of Douglas fir green veneers peeled from heartwood is characterized by high variability. In some parts of the veneer, the surface is very wavy and consisted of regular high peaks and deep cavities, which occurred most often in earlywood. This phenomenon can be seen on the image of the surface in Fig. 5. In the earlywood part, the surface is rough and big differences between the highest and the deepest points exist. The opposite dependence occurs in latewood, where the surface is smooth and roughness parameters are lower by over $50 \%$. 
The presented image shows that the structure of the surface and values of roughness parameters may be considerably different for different areas of the veneer. The explanation of this feature is a different structure and properties of early- and latewood, such as density and structure of cells.

Another element of wood characteristics affecting the surface roughness of veneers are knots. Generally, knots decrease the quality of veneers, because they cause deterioration in mechanical properties of veneer-based boards, such as LVL and plywood. They also have a negative effect on the product aesthetics. Therefore, they are not desirable in veneer manufacturing. In case of the surface roughness, knots may have various effects, depending on their type. The intergrown knots may decrease the surface roughness, because of their higher density. An example of such case is shown in Fig. 6. However, except for intergrown knots, there are other types, for example, encased or decayed knots, which may negatively affect the surface roughness and decrease the quality.

\subsection{The effect of process parameters on the surface roughness of green veneers}

Table 2 contains statistical indicators of $R_{a}$ and $R_{z}$ parameters for centered and non-centered logs. Significant variation of indicators can be observed for each parameter (from 36 to $43 \%$ ), which could be attributed to the heterogeneous structure of Douglas fir. It has been previously reported that factors such as ring widths, density of earlywood and latewood and specific cell structure have an effect on the surface roughness (Mothe et al. 1992; Sachsse and Roffael 1993; Hecker 1995b). The surface roughness and variation of the
Table 2 Results of roughness parameters of centered and non-centered $\log s$

\begin{tabular}{lrrrrrr}
\hline & \multicolumn{2}{c}{ Centered $\log$} & & \multicolumn{2}{c}{ Non-centered log } \\
\cline { 2 - 3 } & \multicolumn{1}{c}{$R_{a}$} & \multicolumn{1}{c}{$R_{z}$} & & \multicolumn{1}{c}{$R_{a}$} & \multicolumn{1}{c}{$R_{z}$} \\
\hline Average $(\mu \mathrm{m})$ & 29.8 & 154.8 & & 46.8 & 246.1 \\
Standard deviation $(\mu \mathrm{m})$ & 12.5 & 55.7 & & 19.8 & 102.7 \\
Variance & 156.3 & 3102.3 & & 393.8 & 6398.8 \\
Coefficient of variation $(\%)$ & 42.0 & 36.0 & 42.4 & 41.7 \\
Normalized kurtosis & 1.59 & 0.76 & -0.90 & -0.58 \\
Skewness & 0.95 & 0.58 & 0.35 & 0.51 \\
\hline
\end{tabular}

results are higher for non-centered logs than for centered logs, which can be explained by a different ring arrangement in the non-centered $\log$ and thus different distribution of late- and earlywood. Both calculated roughness parameters for the non-centered log are higher by approximately $55 \%$ than the ones of centered logs. It was decided to present the results using histograms, which give a more precise information in case of a high number of results. The distribution of the results for centered and non-centered logs is shown in Fig. 7.

As can be seen on the histograms, distributions of the results for both kinds of logs are considerably different. Generally, the results of both analyzed logs are characterized by positive skewness, thus they are right-tailed distributed. However, a non-centered log is characterized by a larger number of high value results, which results in significantly higher mean values of $R_{a}$ and $R_{z}$ for this $\log$.

Table 3 presents results of roughness parameters for $\log$ s soaked in different temperatures. As before, results

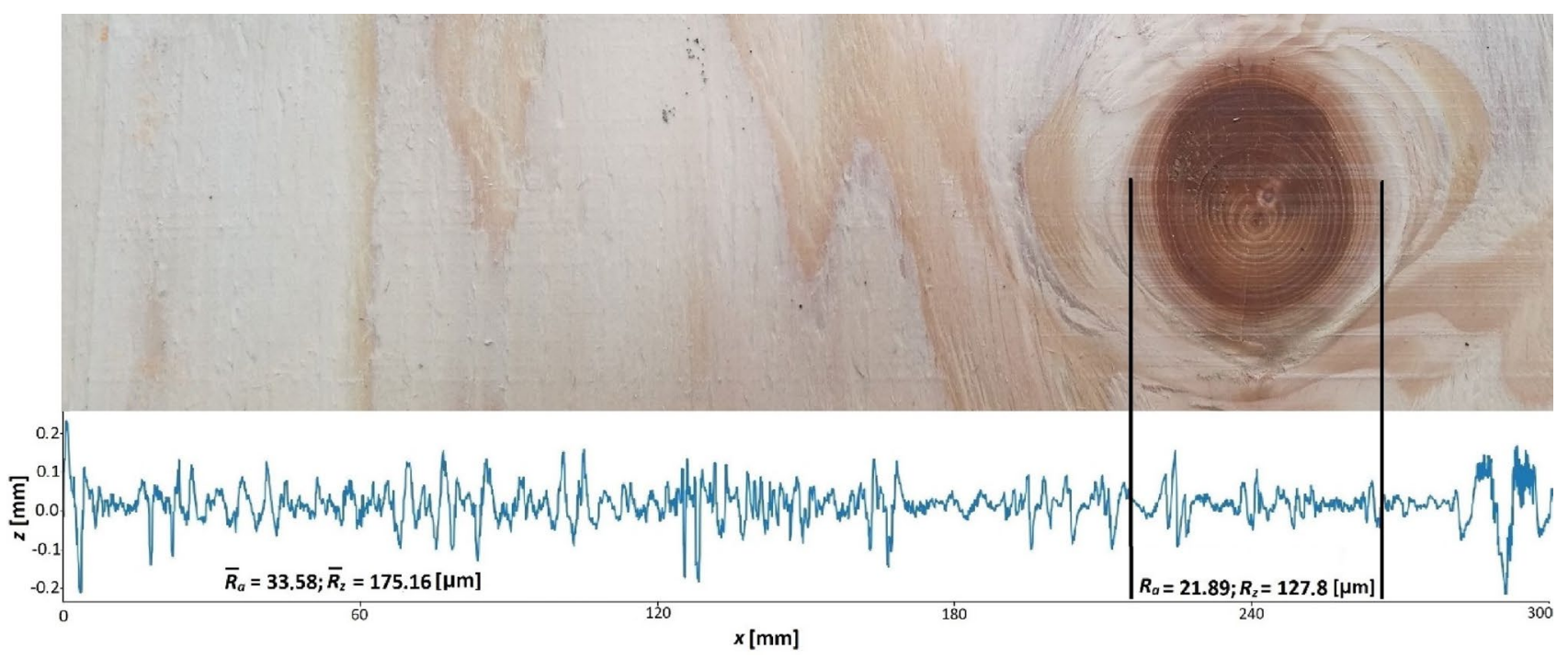

Fig. 6 Roughness profile of intergrown knot compared to regular wood, with calculated roughness parameters of sections before and within the knot 

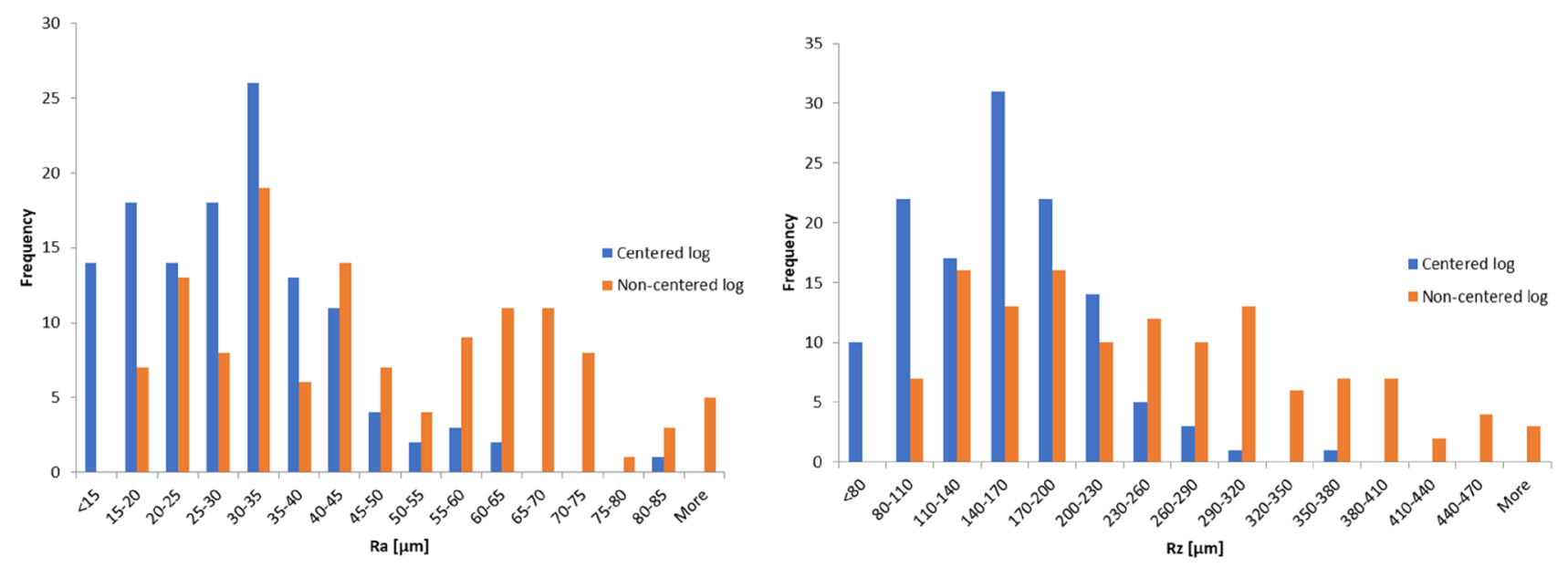

Fig. 7 Distribution of the results of roughness parameters for centered and non-centered logs

Table 3 Results of roughness parameters depending on the soaking temperature

\begin{tabular}{|c|c|c|c|c|}
\hline & \multicolumn{2}{|c|}{$\begin{array}{l}\text { Soaking temp. } \\
55^{\circ} \mathrm{C}\end{array}$} & \multicolumn{2}{|c|}{$\begin{array}{l}\text { Soaking temp. } \\
80^{\circ} \mathrm{C}\end{array}$} \\
\hline & $R_{a}$ & $R_{z}$ & $R_{a}$ & $R_{z}$ \\
\hline Average $(\mu \mathrm{m})$ & 38.0 & 216.9 & 45.8 & 250.5 \\
\hline Standard deviation $(\mu \mathrm{m})$ & 14.2 & 105.2 & 14.8 & 80.5 \\
\hline Variance & 201.3 & $11,059.3$ & 220.1 & 6482.5 \\
\hline Coefficient of variation (\%) & 37.4 & 48.5 & 32.4 & 32.1 \\
\hline Normalized kurtosis & 0.68 & 4.62 & 1.60 & 0.5 \\
\hline Skewness & 0.78 & 1.75 & 0.83 & 0.69 \\
\hline
\end{tabular}

variability is high and amounts up to $49 \%$. Higher roughness values were obtained for logs soaked at $80{ }^{\circ} \mathrm{C}$, which is in an agreement with Corder and Atherton (1963). It may be caused by "softification" of early wood at high temperature, which can produce the Horner effect (Mothe 1988; Marchal et al. 2009; Thibaut et al. 2016).

Based on Fig. 8, it can be seen that the most frequent values of roughness parameters for analyzed logs are considerably different. All distribution parameters are characterized by positive skewness and kurtosis. The distribution of $R_{a}$ parameter is close to a normal distribution. It can be noticed that kurtosis for $R_{z}$ parameter for $55{ }^{\circ} \mathrm{C}$ is clearly higher
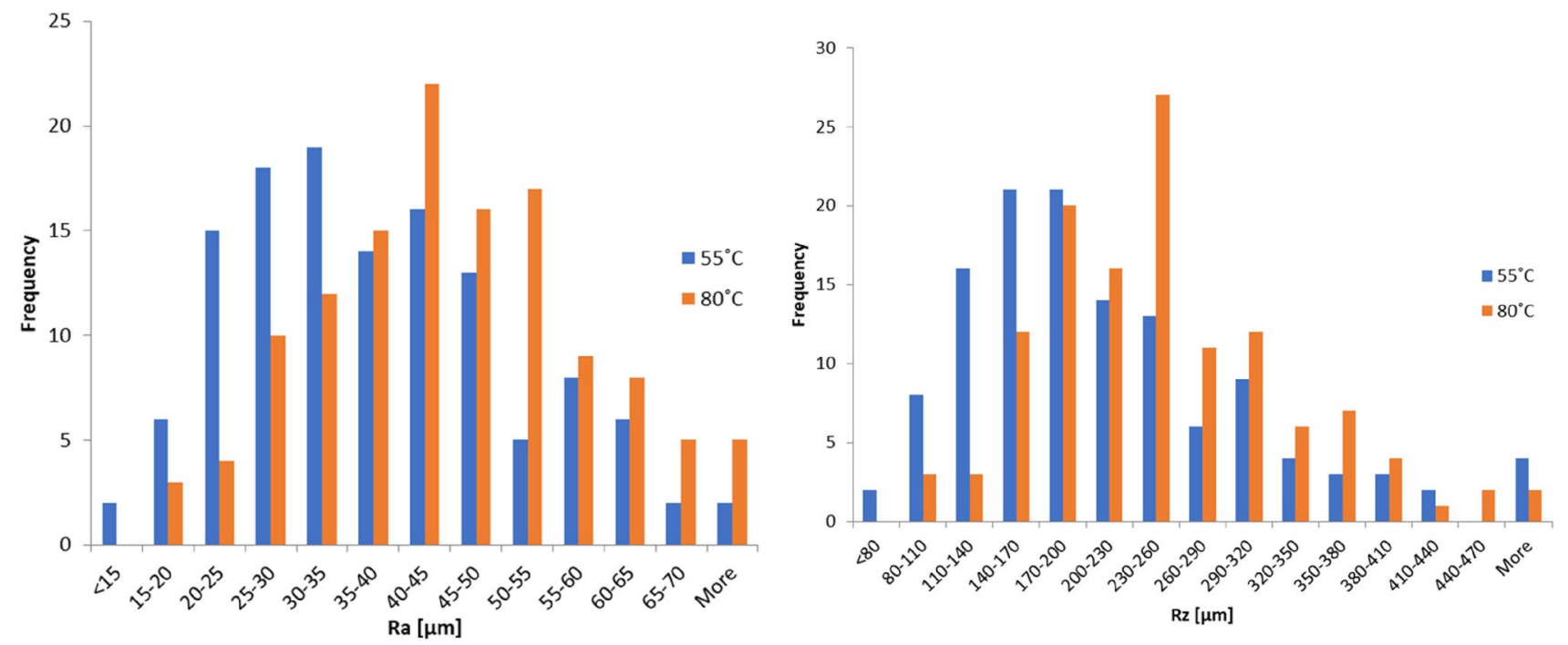

Fig. 8 Distribution of the results of roughness parameters depending on the soaking temperature 
compared to other cases, showing that this distribution is leptokurtic. The surface of the veneer peeled from this log was characterized by similar number of high and low values of $R_{z}$ (distribution is more uniform).

Table 4 presents surface roughness parameters depending on the cutting speed. All the roughness parameters are higher for the cutting speed of $1 \mathrm{~m} / \mathrm{s}$. The reason of this feature is that when the cutting speed is too low, cell wall cannot be cut correctly especially on earlywood, and produces the Horner effect (Mothe 1988; Marchal et al 2009; Thibaut et al. 2016). This phenomenon also concerns different techniques of wood machining, among others veneer production by slicing (Dundar et al. 2008a). It can be seen on the diagrams in Fig. 9 that results of the cutting speed of $1 \mathrm{~m} / \mathrm{s}$ are more evenly distributed (especially distribution of $R_{z}$ results) and characterized by negative kurtosis $(-0.35$ for $R_{a}$ and $R_{z}$ ).

According to the authors conclusions, future research on this subject could be limited to analyze only $R_{z}$ parameter. This approach allows to limit the number of results

Table 4 Surface roughness parameters depending on the cutting speed

\begin{tabular}{lrrrrr}
\hline & \multicolumn{2}{l}{ Cutting speed } & & \multicolumn{2}{l}{ Cutting speed } \\
& \multicolumn{2}{c}{$2 \mathrm{~m} / \mathrm{s}$} & & & \multicolumn{1}{c}{$\mathrm{m} / \mathrm{s}$} \\
\cline { 2 - 3 } \cline { 5 - 6 } & \multicolumn{1}{c}{$R_{a}$} & $R_{z}$ & & $R_{a}$ & \multicolumn{1}{c}{$R_{z}$} \\
\hline Average $(\mu \mathrm{m})$ & 29.8 & 154.8 & & 34.4 & 217.2 \\
Standard deviation $(\mu \mathrm{m})$ & 12.5 & 55.7 & & 15.9 & 80.0 \\
Variance & 156.3 & 3102.3 & & 253.8 & 6398.8 \\
Coefficient of variation $(\%)$ & 42.0 & 36.0 & & 46.3 & 36.8 \\
Normalized kurtosis & 1.59 & 0.76 & -0.35 & -0.35 \\
Skewness & 0.95 & 0.58 & 0.54 & 0.50 \\
\hline
\end{tabular}

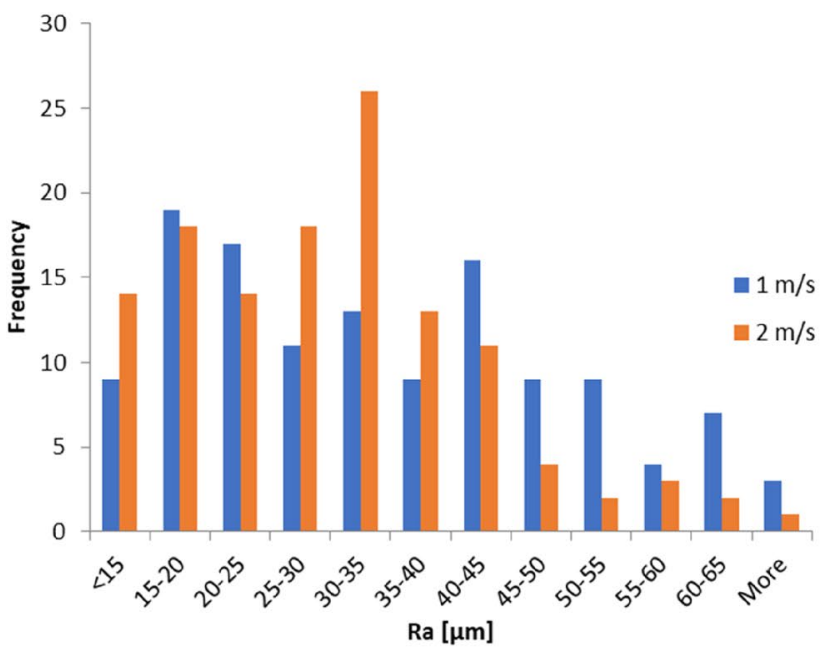

and analyze the surface structure more precisely by focusing just on one parameter.

Table 5 contains statistical analysis of results of the surface roughness of green heartwood veneers. For both analyzed roughness parameters of all tested samples, average values are significantly different at assumed significance level of $\alpha=0.05$.

\section{Conclusion}

This research shows that in-process optical measurement of the surface roughness carried out with the use of a laser profilometer can be effectively useful in the veneer production. Laser measurement has the potential to quantify and evaluate surface roughness, which may be a proper indicator

Table 5 Statistical analysis of the results of the surface roughness obtained during the study

\begin{tabular}{lcc}
\hline & $R_{a}$ & $R_{z}$ \\
\hline Centered log mean $(\mu \mathrm{m})$ & 29.8 & 154.8 \\
Non-centered log mean $(\mu \mathrm{m})$ & 46.8 & 246.1 \\
$\mathrm{t}$ value & 6.25 & 6.99 \\
$\mathrm{P}$ value & $<0.001$ & $<0.001$ \\
Soaking temp. $55^{\circ} \mathrm{C}$ mean $(\mu \mathrm{m})$ & 38.0 & 216.9 \\
Soaking temp. $80^{\circ} \mathrm{C}$ mean $(\mu \mathrm{m})$ & 45.8 & 250.5 \\
$\mathrm{t}$ value & 8.04 & 6.36 \\
$\mathrm{P}$ value & $<0.001$ & $<0.001$ \\
$1 \mathrm{~m} / \mathrm{s}$ mean $(\mu \mathrm{m})$ & 34.4 & 217.2 \\
$2 \mathrm{~m} / \mathrm{s}$ mean $(\mu \mathrm{m})$ & 29.8 & 154.8 \\
$\mathrm{t}$ value & 8.71 & 13.49 \\
$\mathrm{P}$ value & $<0.001$ & $<0.001$ \\
\hline
\end{tabular}

Fig. 9 Distribution of the results of roughness parameters depending on the cutting speed 
of green veneer quality. The investigation shows that using a laser profilometer allows finding differences in the surface roughness of green veneers peeled in various conditions. The surface quality of the heartwood veneers is significantly different depending on the parameters of both pre-treatment and peeling processes. It has been found that veneer surface roughness is sensitive to soaking temperature. Values of roughness parameter were the lowest when the soaking temperature was $65^{\circ} \mathrm{C}$ and the highest when the soaking temperature was $80^{\circ} \mathrm{C}$. More experiments are required in this regard. Peeling of well-centered core $\log$ is also favorable because irregular distribution of early- and latewood has a negative effect on the surface quality. This configuration $\left(2 \mathrm{~m} / \mathrm{s}\right.$, centered, $\left.65^{\circ} \mathrm{C}\right)$ allows obtaining the lowest surface roughness in the range of the conducted experiments.

Moreover, the origin of the surface roughness of Douglas fir veneers was analyzed, including the effect of the structure and properties of wood on the surface roughness. Structure of the surface is very diverse depending on location in the veneer. The surface roughness is considerably higher for earlywood than for latewood for Douglas fir, what is connected to higher density and different structure of cells in latewood. For this reason, the results are characterized by high variation, which in some cases amounts up to $50 \%$. Statistical analysis showed that in the range of the conducted experiments, the log centration, the soaking temperature and the cutting speed have a significant effect on the surface roughness of green Douglas fir veneers peeled from heartwood.

Acknowledgements The authors gratefully acknowledge the financial support from the Bourgogne Franche-Comté region, the Ministère de l'Alimentation et de l'Agriculture Francais and the Xylomat Technical Platform from the Xylomat Scientific Network funded by ANR10-EQPX-16 XYLOFOREST. The study was done during Erasmus + internship for PhD students.

\section{Compliance with ethical standards}

Conflict of interest On behalf of all authors, the corresponding author states that there is no conflict of interest.

\section{References}

Aydin I, Colakoglu G, Hiziroglu S (2006) Surface characteristics of spruce veneers and shear strength of plywood as a function of log temperature in peeling process. Int J Solids Struct 43:6140-6147

Bekhta P, Proszyk S, Krystofiak T, Mamonova M, Pinkowski G, Lis B (2014) Effect of thermomechanical densification on surface roughness of wood veneers. Wood Mat Sci Eng 9:233-245

Bekhta P, Proszyk S, Krystofiak T, Sedliacik J, Novak I, Mamonova M (2017) Effects of short-term thermomechanical densification on the structure and properties of wood veneers. Wood Mat Sci Eng 12:40-54

Csanády E, Magoss E (2013) Mechanics of wood machining, 2nd edn. Springer, Berlin
Candan Z, Hiziroglu S, McDonald AG (2010) Surface quality of thermally compressed Douglas fir veneer. Mater Des 31:3574-3577

Corder S E, Atherton G H (1963) Effect of peeling temperatures on Douglas fir veneer. Information circular 18, Forest Research Laboratory, Oregon State University, Corvallis, Oregon, USA

DeVallance DB, Funck JW, Reeb JE (2007) Douglas-fir plywood gluebond quality as influenced by veneer roughness, lathe checks, and annual ring characteristics. For Prod J 57:21-28

Diouf PN, Stevanovic T, Cloutier A, Fang CH, Blanchet P, Koubaa A, Mariotti N (2011) Effects of thermo-hygro-mechanical densification on the surface characteristics of trembling aspen and hybrid poplar wood veneers. Appl Surf Sci 257:3558-3564

Dundar T, Akbulut T, Korkut S (2008a) The effects of some manufacturing factors on surface roughness of sliced Makore (Tieghemella heckelii Pierre Ex A. Chev.) and rotary-cut beech (Fagus orientalis L.) Veneers. Build Environ 43:469-474

Dundar T, As N, Korkut S, Unsal O (2008b) The effect of boiling time on the surface roughness of rotary-cut veneers from oriental beech (Fagus orientalis L.). J Mater Process Technol 199:119-123

Dupleix A, Denaud LE, Bleron L, Marchal R, Hughes M (2013) The effect of $\log$ heating temperature on the peeling process and veneer quality: beech, birch, and spruce case studies. Eur J Wood Prod 71:163-171

Echols RM (1973) Uniformity of wood density assessed from X-rays of increment cores. Wood Sci Technol 7:34-44

Faust TD, Rice JT (1986) Effects of veneer surface roughness on gluebond quality in southern pine plywood. For Prod J 36:57-62

Funck JW, Forrer JB, Butler DA, Brunner CC, Maristany AG (1993) Measuring surface roughness on wood: a comparison of laserscatter and stylus-tracing approaches. Ind Appl Opt Inspect Metrol Sens 1821:173-185

Goli G, Sandak J (2016) Proposal of a new method for the rapid assessment of wood machinability and cutting tool performance in peripheral milling. Eur J Wood Prod 74:867-874

Hecker M (1995a) Peeled veneer from Douglas-fir: influence of round wood storage, cooking and peeling temperature on surface roughness. In: Proceedings of the 12th International Wood Machining Seminar. Dep. of Wood Science and Technology, Faculty of Agriculture, Kyoto, pp 92-101

Hecker M (1995b) Die Oberflächen-Rauhigkeit von Messerfurnier und Schälfurnier der Douglasie (Pseudotsuga menziesii (Mirb.) Franco) in Abhängigkeit von Bestandesbehandlung und Furniertechnik [The surface roughness of sliced veneer and peeled veneer of Douglas fir (Pseudotsuga menziesii (Mirb.) Franco) depending on stand treatment and veneer technique]. Dissertation Forstl. Fak. Univ. Göttingen

ISO 4287 (1997) Geometrical product specifications (GPS)—surface texture: profile method-terms, definitions, and surface texture parameters. International Organization for Standardization, Geneva, Switzerland

ISO 4288 (1996) Geometrical product specifications (GPS)—surface texture: profile method - rules and procedures for the assessment of surface texture. International Organization for Standardization, Geneva

Kilic M, Hiziroglu S, Burdurlu E (2006) Effect of machining on surface roughness of wood. Build Environ 41:1074-1078

Lundberg IÅS, Porankiewicz B (1995) Studies of non-contact methods for roughness measurements on wood surfaces. Holz Roh Werkst 53:309-314

Marchal R, Mothe F, Denaud LE, Thibaut B, Bleron L (2009) Cutting forces in wood machining-Basics and applications in industrial processes. A review COST Action E35 2004-2008: Wood machining-micromechanics and fracture. Holzforschung 63:157-167

Mothe F (1988), Aptitude au déroulage du bois de douglas. Conséquences de l'hétérogénéité du bois sur la qualité des placages. 
(Douglas fir peeling process ability : Wood heterogeneity effect on veneer quality). Thesis Université Henri Poincaré, Nancy

Mothe F, Movassaghi H, Thibaut B (1992) The results of Douglas and Epicea: some research results. For Enterprise 80:28-36

Neese JL, Reeb JE, Funck JW (2004) Relating traditional surface roughness measures to gluebond quality in plywood. For Prod J 54:67-73

Rohumaa A, Antikainen T, Hunt CG, Frihart CR, Hughes M (2016) The influence of log soaking temperature on surface quality and integrity performance of birch (Betula pendula Roth) veneer. Wood Sci Technol 50:463-474

Sachsse H, Roffael E (1993) Untersuchung der Schälfurner-Eignung von in Deutschland erwachsenem Douglasienholz. [Investigations on the suitability of Douglas fir, grown in germany, for the production of rotary cut veneer]. Holz Roh- Werkst 51:167-176

Sandak J, Negri M, Tanaka C (2004) Sensors for evaluation of wood surface smoothness. In: Proceedings of the 2nd international symposium on wood machining. BOKU-University of Natural Resources and Applied Life Sciences, Vienna, pp 343-350

Sandak J, Tanaka C (2003) Evaluation of surface smoothness by laser displacement sensor 1: Effect of wood species. J Wood Sci 49:305-311
Sogutlu C (2017) Determination of the effect of surface roughness on the bonding strength of wooden materials. BioResources 12:1417-1429. https://doi.org/10.15376/biores.12.1.1417-1429

Tanritanir E, Hiziroglu S, As N (2006) Effect of steaming time on surface roughness of beech veneer. Build Environ 41:1494-1497

Bernard T, Louis D, Robert C, Rémy M, Jacques B, Frédéric M, PierreJean M, Patrick M, Pierre L, Florent E (2016) Wood machining with a focus on french research in the last 50 years. Ann For Sci 73(1):163-184. https://doi.org/10.1007/s13595-015-0460-2

Thoma H, Peri L, Lato E (2015) Evaluation of wood surface roughness depending on species characteristics. Maderas-Cienc Tecnol 17:285-292

Vonnet G, Perrin JR, Ferrand JC (1985) Consideration on wood density. Part 4: density and heterogeneity of Douglas fir wood. Holzforschung 39:273-279

Publisher's Note Springer Nature remains neutral with regard to jurisdictional claims in published maps and institutional affiliations. 